\title{
Some observations on vertical distribution and migration of the phototrophic ciliate Mesodinium rubrum (= Myrionecta rubra) in a stratified brackish inlet
}

\author{
David W. Crawford ${ }^{1, *}$, Tore Lindholm ${ }^{2}$ \\ ${ }^{1}$ Department of Oceanography, University of Southampton, Southampton Oceanography Centre, European Way, \\ Southampton SO14 3ZH, United Kingdom \\ ${ }^{2}$ Ábo Akademi University, Department of Biology, Biocity, SF-20520 Turku, Finland
}

\begin{abstract}
The vertical distribution of the phototrophic ciliate Mesodinium rubrum (= Myrionecta rubra) was examined under relatively stable conditions in Inre Verkviken, a brackish inlet on the Aland Islands, Finland, in early summer 1991. Distribution was characterized by a population maximum situated persistently within the thermocline ( 8 to $11 \mathrm{~m}$ depth) just above the nitracline, and at an irradiance $\left(\sim 1\right.$ to $10 \mu \mathrm{mol}$ photons $\left.\mathrm{m}^{-2} \mathrm{~s}^{-1}\right)$ below the estimated irradiances required either for photosynthetic saturation $\left(I_{\mathrm{k}} \approx 275 \mu \mathrm{mol}\right.$ photons $\left.\mathrm{m}^{-2} \mathrm{~s}^{-1}\right)$ or even compensation $\left(I_{\mathrm{c}} \approx 15 \mu \mathrm{mol}\right.$ photons $\left.\mathrm{m}^{-2} \mathrm{~s}^{-1}\right)$. This population maximum often co-occurred with a second deeper maximum at around 14 to $16 \mathrm{~m}$, with transient evidence of a third poorly defined peak within the upper $5 \mathrm{~m}$. Maximum cell numbers reached over 200 cells $\mathrm{ml}^{-1}$ at $15 \mathrm{~m}$, but were more typically observed at around 50 to 100 cells $\mathrm{ml}^{-1}$ within the 2 lower population maxima. Cells were usually present at all depths down to the anoxic boundary (15 to $16 \mathrm{~m}$ ), but were occasionally almost absent from the surface few metres. Total depth integrated population (over 0 to $20 \mathrm{~m}$ ) was of the order $550 \times 10^{6}$ to $900 \times 10^{6} \mathrm{cells} \mathrm{m}^{-2}$, only a factor of about 2 lower than typical red-water integrated abundances. Despite the distinct vertical separation between irradiance and dissolved nutrients, no consistent diel pattern of vertical migration was discerned. Apparent movements of maxima were observed but were not associated with diel changes in the depth of either $I_{k}$ or $I_{c}$. Given the exceptional swimming speed and photosynthetic efficiency of $M$. rubrum, and these complicated changes in distribution, a diel migration pattern may not be necessary, and we speculate that migration might occur on an 'individual needs' basis. However, this migration potential was a constant logistical complication hampering temporal and spatial sampling design, and artefactual changes in distribution cannot be ruled out. Improved future understanding of the migration of this species will only be realized with a much more dynamic approach to sampling in order to minimize the possibility that migration might be quicker than data collection.
\end{abstract}

KEY WORDS: Mesodinium rubrum - Myrionecta rubra - Planktonic ciliates - Vertical distribution · Vertical migration

\section{INTRODUCTION}

The photosynthetic planktonic ciliate Mesodinium rubrum $^{1}$ (Lohmann) Hamburger \& Buddenbrock (= Myrionecta rubra Jankowski) has an exceptional swimming speed of some 5 to $8.5 \mathrm{~mm} \mathrm{~s}^{-1}$ (Lindholm 1985, Jonsson \& Tiselius 1990), an order of magnitude quicker than most

\footnotetext{
- Present address: Department of Oceanography, University of British Columbia, 6270 University Boulevard, Vancouver, British Columbia, Canada V6T 1 Z4

E-mail: dcrawford@unixg.ubc.ca
}

dinoflagellates. Surface, near-surface and deeper accumulations are characteristics of reports of $M$. rubrum, both in red water and non-bloom conditions (for reviews see Taylor et al. 1971, Lindholm 1985, Crawford

\footnotetext{
${ }^{1}$ We retain the name Mesodinium rubrum over the more recently proposed Myrionecta rubra (see Small \& Lynn 1985, Krainer \& Foissner 1990). The life cycle of $M$. rubrum is unknown, the obligate nature of the symbiosis has never been confirmed beyond doubt, and profound variations in size and morphology occur in both red water and non-bloom populations (e.g. Taylor et al. 1971, Lindholm 1985, Crawford 1993). For these reasons we feel that changes in nomenclature are premature.
} 
1989), and an improved understanding of vertical distribution and migration may give some clues as to the mechanisms involved in the appearance of red water.

Information on the vertical distribution of Mesodinium rubrum in stable water bodies is available for different seasons (Lindholm 1981, Dale 1987, Lindholm \& Mörk 1990), but the dynamics of distribution and migration on smaller temporal and spatial scales, and in open water conditions, are clearly complex and not well understood (e.g. Lindholm \& Mörk 1990, Crawford \& Purdie 1992, Owen et al. 1992, Cloern et al. 1994, Crawford et al. 1997). Vertical migration is not limited by depth, at least down to $40 \mathrm{~m}$ (Smith \& Barber 1979, Sorokin \& Kogelschatz 1979), and gradients in temperature, salinity and dissolved oxygen seem to pose no barrier (Taylor et al, 1971, Lindholm 1985). The behaviour of $M$. rubrum has usually been assumed to consist of an upward phototaxis (Bary \& Stuckey 1953, Smith \& Barber 1979) followed by downward migration, or dispersal, at night (Soulsby et al. 1984). Passow (1991) suggested that the presumed light dependent migration by $M$. rubrum might be complicated by another unmeasured environmental parameter and indeed, more recently, Crawford \& Purdie (1992) proposed that a direct motile response to turbulence could be a complicating factor.

As Mesodinium rubrum cannot yet be cultured, a stable 'mesocosm-like' environment probably provides the best source of further information, as both turbulence and advective horizontal displacement of the population are minimized. Here we present some observations on the vertical distribution and migration of $M$. rubrum in such an environment with the added advantage that the population was constrained to a vertical distance of only $20 \mathrm{~m}$, allowing relatively close interval sampling through the whole population.

\section{METHODS}

The study was undertaken at Husö Biological Station (Åland Islands, Bothnian Sea, off southwestern Finland), and sampling conducted in Inre Verkviken, a $20 \mathrm{~m}$ deep fjord-like brackish inlet (for map, see Lind-

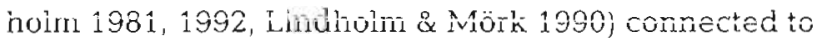
the Bothnian Sea via a $200 \mathrm{~m}$ long, $1 \mathrm{~m}$ deep canal. Inre Verkviken is currently going through a meromictic phase (Lindholm 1996).

Sampling was conducted from a rowing boat approximately in the centre and deepest part of the lake. Profiles of physical parameters were taken at intervals of $1 \mathrm{~m}$; temperature and salinity were recorded with a YSI probe and irradiance with a Li-Cor $188 \mathrm{~B}$ radiometer. Water samples were taken with a Ruttner-type sampler, down to $18-20 \mathrm{~m}$, at close intervals of either
$0.5,1.0$ or $2.0 \mathrm{~m}$ in order to minimize underestimation of population maxima (e.g. Crawford 1989). Subsamples were removed for cell counts, oxygen concentration, chlorophyll a ( $\mathrm{chl}$ a), and in some profiles total phosphorus and dissolved nitrate. Samples for enumeration of Mesodinium rubrum were dispensed directly from the sampler into glass bottles containing acid Lugol's iodine preservative, with a final concentration of $1 \% \mathrm{v} / \mathrm{v}$ (Throndsen 1978, Crawford 1989). On-site preservation minimized the possibility of lysis of cells during transport back to the laboratory since M. rubrum is particularly fragile (Lindholm 1985 . Crawford 1989). M. rubrum was enumerated from 10 or $25 \mathrm{ml}$ subsamples in Hydrobios sedimentation chambers using a Nikon inverted microscope. Cell number was calculated as the mean trom 5 passes across the base of the sedimentation chamber, with a typical number per pass being around 50 (in a $10 \mathrm{ml}$ chamber with cell number at $100 \mathrm{ml}^{-1}$ ).

Dissolved oxygen and nitrate, and chl a were determined according to Parsons et al. (1984), and total phosphorus (particulate plus dissolved) according to Grasshoff (1976).

\section{RESULTS AND DISCUSSION}

A single exploratory depth profile was taken on 27 May in order to demonstrate typical daytime conditions (Fig. 1) and shows a weak halocline and a reasonably strong thermocline. The bulk of the population of Mesodinium rubrum was residing at depth and was distributed as 2 maxima, perhaps with evidence of a poorly defined third maximum in the upper $5 \mathrm{~m}$. Cells were present at all depths down to about $18 \mathrm{~m}$, with maximum abundance at around $100 \mathrm{ml}^{-1}$ within the population maxima. The central population maximum was located within the thermocline, as marked visually (Fig. 1) by the zone between the 5 and $10^{\circ} \mathrm{C}$ isotherms. Counting error is indicated and the mean coefficient of variation varied from about $3 \%\left( \pm 5\right.$ cells $\left.\mathrm{ml}^{-1}\right)$ at abundances of over 100 cells $\mathrm{ml}^{-1}$ to about $70 \%( \pm 0.4$ cells $\mathrm{ml}^{-1}$ ) at abundances of less than 1 cell $\mathrm{ml}^{-1}$. Sampling error was estimated from 4 replicate bottle samples takcn from $10 \mathrm{~m}$ depth; mean count from the 4 replicate bottles was 99.0 cells $\mathrm{ml}^{-1}\left( \pm 1.4\right.$ cells $\mathrm{ml}^{-1}$ standard error). Although a 1 -way ANOVA gave no significant difference between the counts from the 4 replicates, it is unlikely whether such replication would have held under all circumstances, for example when a population maximum was migrating. The total integrated population of $M$. rubrum between 0 and $20 \mathrm{~m}$ was $761 \times 10^{6}$ cells $\mathrm{m}^{-2}$.

Chl a clearly showed a similar trend to cell numbers (Fig. 1) suggesting that Mesodinium rubrum was the 
dominant chl a containing species. With cell numbers of $100 \mathrm{ml}^{-1}$, and assuming a mean cell diameter of $30 \mu \mathrm{m}$ and chl a content of $2.4 \mathrm{fg}_{\mathrm{\mu m}^{-3}}$ (Stoecker et al. 1991), this gives a theoretical chl a concentration of around $4 \mu \mathrm{g} \mathrm{l}^{-1}$ for $M$. rubrum alone. Ambient concentrations of chl $a$ in the population maxima were around

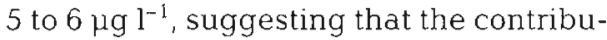
tion of $M$. rubrum was of the order of 70 to $80 \%$.

Compensation irradiance $\left(I_{\mathrm{c}}\right)$ can be defined as irradiance $(I)$ at which photosynthetic rate $(P)$ just exceeds respiration rate $(R)$. There are no published values of $I_{\mathrm{C}}$ for Mesodinium rubrum, but this was crudely calculated from $R$, and the assumption of a simplistic linear relationship between $P$ and $I$ up to saturation irradiance $\left(I_{\mathrm{k}}\right)$ at which $P_{\max }$ is achieved. $I_{\mathrm{k}}$ has been estimated at around $275 \mu \mathrm{mol} \mathrm{m} \mathrm{m}^{-2} \mathrm{~s}^{-1}$ when $P_{\max }$ is around 11 to $14 \%$ cell $\mathrm{C} \mathrm{h}^{-1}$ (Stoecker et al. 1991), and $R$ has been estimated at about $0.7 \%$ cell $\mathrm{C} \mathrm{h}^{-1}$ from a careful review of published rates of $\mathrm{O}_{2}$ consumption and $\mathrm{CO}_{2}$ production from incubations of red water caused by $M$. rubrum (Crawford 1992a). Using these values, a value for $I_{c}$ of $15 \mu \mathrm{mol}$ photons $\mathrm{m}^{-2} \mathrm{~s}^{-1}$ was calculated (Fig. 1; see also Crawford et al. 1997). In situ I (4 to $13 \mu \mathrm{mol}$ photons $\mathrm{m}^{-2} \mathrm{~s}^{-1}$ ) was lower than $I_{c}$ within the central population maximum ( 8 to $10 \mathrm{~m}$ ) and barely detectable $\left(\ll 1 \mu \mathrm{mol}\right.$ photons $\mathrm{m}^{-2} \mathrm{~s}^{-1}$ ) in the lower maximum (14 to $16 \mathrm{~m}$ ). Within the upper 4 to $6 \mathrm{~m}$, variation in in situ I was of the order 40 to $1200 \mu \mathrm{mol}$ photons $\mathrm{m}^{-2} \mathrm{~s}^{-1}$, although the shallow $I_{\mathrm{k}}$ depth suggested that only a small proportion of the population was subject to ir radiance in excess of $I_{\mathrm{k}}$ at a given time.

Dissolved oxygen exceeded saturation near the surface and remained constant down to a depth of about 7 to $8 \mathrm{~m}$, below which concentration declined sharply with depth (Fig. 1). The depth of this decline coincided almost exactly with the depth of estimated $I_{c \text {, }}$ consistent with $I_{c}$ representing a realistic in situ compensation intensity when Mesodinium rubrum was dominant. At about $16 \mathrm{~m}$ the water became almost anoxic; oxygen concentration did not quite reach zero values $\left(0.1\right.$ to $\left.0.3 \mathrm{mg} \mathrm{O}_{2} \mathrm{l}^{-1}\right)$, perhaps, for example, due to small amounts of oxygen introduced with Winkler reagents. However, an odour of $\mathrm{H}_{2} \mathrm{~S}$ from samples below 16 to $17 \mathrm{~m}$ suggests that this water probably was anoxic. A value of $0.5 \mathrm{mg} \mathrm{O}_{2} \mathrm{l}^{-1}$ (about $5 \%$ saturation) was arbitrarily defined as the 'anoxic' boundary for graphical purposes $\left(\mathrm{zO}_{2} ;\right.$ Fig. 1$)$. The deeper abun- dance maximum of $M$. rubrum seemed to be constrained by this boundary as a lower limit, although a few individuals were observed even below this down to $19 \mathrm{~m}$ (see also Lindholm \& Mörk 1990).

Surface nutrients were low (Fig. 1) and the central population maximum resided just above the nitracline. Nitrate was between 0.1 and $0.5 \mu \mathrm{mol} \mathrm{l}^{-1}$ in the surface $10 \mathrm{~m}$, but increased sharply below this depth to maximum values of over $4 \mu \mathrm{mol} \mathrm{l}^{-1}$ in the deeper less oxygenated water. In the 'anoxic' water below $16 \mathrm{~m}$, nitrate declined sharply, perhaps due to anaerobic denitrification processes in the reducing environment. Phosphorus concentrations increased with nitrate in the 10 to $15 \mathrm{~m}$ depth range, but phosphorus was present in concentrations of 0.5 to $1.5 \mu \mathrm{mol} \mathrm{l^{-1 }}$ throughout the water column, suggesting that nitrogen was the limiting nutrient. Unfortunately, only total phosphorus was determined, but crude estimation from Redfield ratios and chlorophyll or cell carbon (i.e. from abundance of Mesodinium rubrum) gave a maximum particulate phosphorus of only about $0.1 \mu \mathrm{mol} \mathrm{l}^{-1}$, suggesting that the greatest proportion of the total phosphorus was in the dissolved form. 


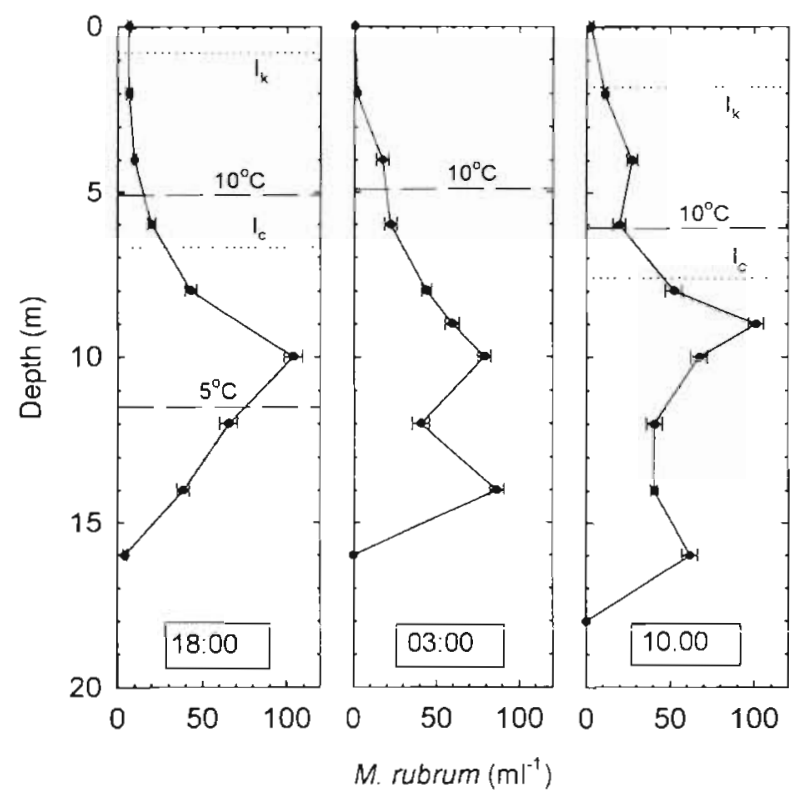

Fig. 2. Mesodinium rubrum. Inre Verkviken, 28 and 29 May 1991; sequence of profiles of abundance taken at 18:00, 03:00 and 10:00 h. Horizontal long-dashed lines, dotted lines and labels as in Fig. 1. Surface irradiance at 03:00 h was below detection limit. $\mathrm{O}_{2}$ profiles not taken, temperature profiles incomplete at $03: 00$ and $10: 00 \mathrm{~h}$

An important consideration relating to this first exploratory profile (Fig. 1) was the time required to sample all of the relevant parameters. Using a single water bottle, and 2 additional separate rigs for temperature and salinity, and for irradiance, this profile required well over $2 \mathrm{~h}$ to complete. This became a critical logistical consideration, given the migration potential of Mesodinium rubrum; if sampling time for one particular profile became 'temporally stretched', then the vertical position of the population could conceivably have changed during the course of sampling. This placed constraints on how many parameters could be sampled and explains why some are missing from subsequent profiles.

In order to highlight potential differences veiween daytinie and rightitime distribution, a sequence of lower resolution depth profiles was taken between the evening of 28 and morning of 29 May (Fig. 2). At 18:00 h the distribution was in the form of a single, though 'smeared' maximum centred at around $10 \mathrm{~m}$, but with cells observed at all depths down to $16 \mathrm{~m}$. At 03:00 $\mathrm{h}$, this distribution had split into 2 lower maxima, with evidence perhaps of the formation of an upper one at around 4 to $5 \mathrm{~m}$. By 10:00 h, these maxima persisted with the upper one slightly more pronounced, and the lower 2 further apart. Significant numbers of cells (>20 $\mathrm{ml}^{-1}$ ) occurred at all depths down to the 'anoxic' boundary. The total integrated populations over 0 to $20 \mathrm{~m}$ were $598 \times 10^{6}, 601 \times 10^{6}$ and $699 \times 10^{6}$ cells $\mathrm{m}^{-2}$ at 18:00, 03:00 and 10:00 h respectively. In terms of the population potentially residing at a preferential isolume, there was no evidence that changes in depths of either $I_{\mathrm{c}}$ or $I_{\mathrm{k}}$ influenced the vertical distribution of the population. Again, the central population maximum seemed to maintain itself in the thermocline zone, although there was evidence of limited movement of the upper and lower maxima into zones respectively replete in irradiance and nutrients. For the profiles above, sampling intervais were reduced to a few hours, and so Mesodinium rubrum could theoretically have made several surface-bottom migrations in between profiles. It was clear from these initial exploratory surveys that conflicting spatial and temporal logistics dictated that sampling for all parameters at 1 or even $2 \mathrm{~h}$ intervals was impossible. A $24 \mathrm{~h}$ survey could only be achieved by reducing the sampling frequency to every $4 \mathrm{~h}$ or so, in which case, the population distribution could conceivably change both within and between profiles.

A further sequence of profiles was taken on the morning of 4 June 1991 (Fig. 3) in which it was attempted to extract as much information as possible from a 2-hourly sampling framework. At 06:00 h, 2 abundance maxima
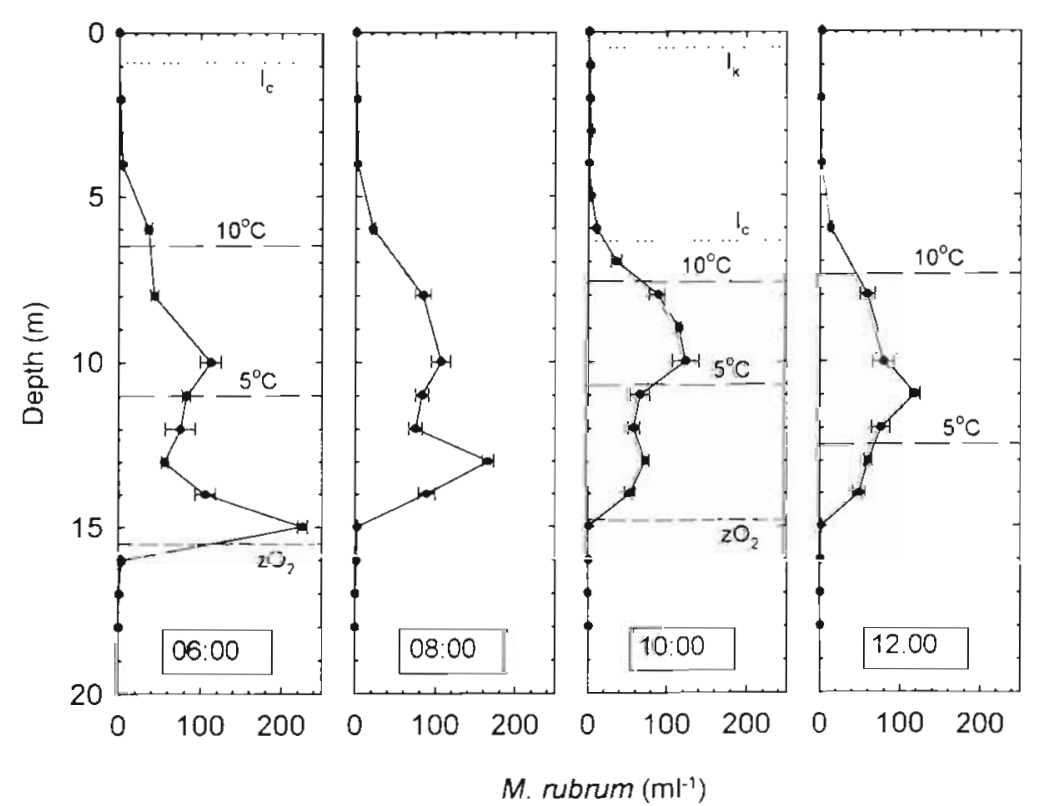

Fig. 3. Mesodinium rubrum. Inre Verkviken, 4 June 1991; sequence of profiles of abundance taken at 06:00,08:00,10:00 and 12:00 h. Horizontal long-dashed lines, short-dashed lines, dotted lines, and labels as in Fig. 1. Irradiance and $\mathrm{O}_{2}$ profiles not taken at 08:00 and 12:00 $\mathrm{h}_{\mathrm{i}}$ temperature not taken at 08:00 $\mathrm{h}$ 


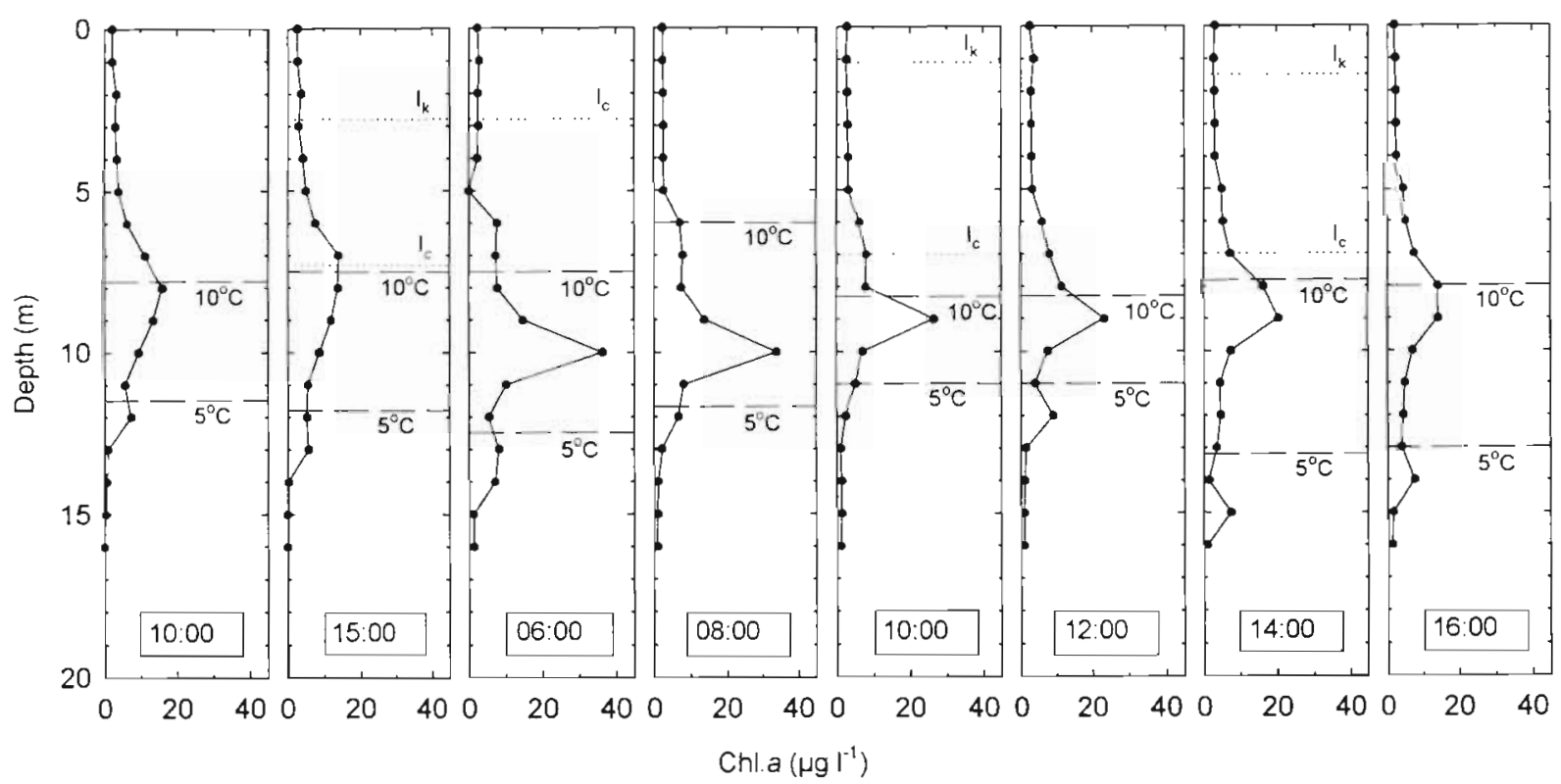

Fig. 4. Inre Verkviken, 10 and 11 June 1991; sequence of profiles of chl a over a period of $30 \mathrm{~h}$. Horizontal long-dashed lines, dotted lines, and labels as in Fig. 1. Irradiance profiles not taken at 10:00 h on 10 June, or at 08:00, 12:00 and 16:00 h on 11 June

were apparent, with evidence of an additional poorly defined upper maximum; cells were present throughout the water column but in very low numbers in the surface $5 \mathrm{~m}$. A marked lower maximum (>200 cells $\mathrm{ml}^{-1}$ ), constrained by the 'anoxic' water below, appeared to migrate upwards throughout the morning. By 12:00 $\mathrm{h}$ the population was distributed as 1 single maximum with its peak at around 10 to $11 \mathrm{~m}$, and few cells in the upper $6 \mathrm{~m}$. The apparent 'mobility' of the 'anoxic' boundary during this period could possibly reflect significant consumption of oxygen during the migration of a large number of cells. Changes in $I_{\mathrm{c}}$ and $I_{\mathrm{k}}$ depths had little impact upon the distribution of the population, and the central population maximum was again largely constrained to the thermocline zone. Total integrated populations from 0 to $20 \mathrm{~m}$ were $833 \times 10^{6}, 746 \times 10^{6}$, $637 \times 10^{6}$ and $548 \times 10^{6}$ cells m $\mathrm{m}^{-2}$ at 06:00, 08:00, 10:00 and $12: 00 \mathrm{~h}$ respectively.

A more extensive series of vertical profiles is presented from 10 and 11 June (Fig. 4), although using chl a concentration as an index of biomass and with temporal spacing between profiles at times rather lengthy. Maximum values of chl a approached $40 \mu \mathrm{g}$ $\mathrm{l}^{-1}$. Although Mesodinium rubrum was dominant, other species clearly made a contribution and so chl a distributions probably did not reflect those of $M$. rubrum in such a clear-cut manner as in Fig. 1. However, as observed with cell abundance, the population was typically distributed as 1 ( 8 to $10 \mathrm{~m}$ ) or 2 (lower one 14 to $16 \mathrm{~m})$ maxima with a 'smeared' distribution in the upper 6 to $7 \mathrm{~m}$. The central maximum changed position by only about $2 \mathrm{~m}$ throughout the entire sampling period and was again generally constrained to the thermocline. As observed in earlier profiles, there was evidence that, when present, the lower maximum occasionally 'dipped' down to the approximate depth of the 'anoxic' boundary (although oxygen data not collected here). Even over a period of some $30 \mathrm{~h}$ there was no evidence that the depth of either $I_{k}$ or $I_{c}$ (when measured) had any significant impact upon the vertical distribution of the population. Total integrated chl a over 0 to $20 \mathrm{~m}$ varied between 87 to $120 \mathrm{mg} \mathrm{chl} \mathrm{a} \mathrm{m}^{-2}$ over the sampling period. Using the regression of chl a:cell number presented by Crawford et al. (1997) and assuming $M$. rubrum represented $75 \%$ of chl a (see Fig. 1), these integrated chl a values represent integrated populations of $M$. rubrum of the order of $650 \times 10^{6}$ to $900 \times 10^{6}$ cells $\mathrm{m}^{-2}$.

The most persistent feature of the study (Figs. 1-4) was the position of the central population maximum within the thermocline between the $I_{\mathrm{c}}$ depth and the nitracline. This observation is consistent with the notion that, like dinoflagellates, the vertical distribution of the population of Mesodinium rubrum may become a compromise between nutrient limitation in surface waters, and light limitation below around 6 to $8 \mathrm{~m}$ depth. This is supported by the observation that when incubated at the surface, samples of nutrient rich deeper water from this inlet were highly productive (Lindholm \& Mörk 1990). Despite reasonable evidence of changes in vertical distribution with time, there was no clear diel pattern of population movements, supporting the preliminary contentions of Lindholm \& Mörk (1990) from autumn profiles of $M$. rubrum in this inlet. Vertical 
distribution generally suggested light limitation for much of the population, but there was no evidence that limited bulk migrations were associated with phototaxis alone. Moreover, it is clear from the extremely shallow $I_{\mathrm{k}}$ depths that distribution patterns did not result from avoidance of excessive irradiance in surface water, and so it is unlikely that photoinhibition plays any significant role in vertical distribution. In any case, evidence to date suggests that $M$. rubrum exhibits minimal photoinhibition even at high irradiance (Smith \& Barber 1979, Platt et al. 1980, Stoecker et al. 1991).

Although Mesodinium rubrum in Inre Verkviken appears to be compromised between irradiance and nutrients, changes in vertical distribution observed here contrast with certain dinoflagellates which have been reported to migrate with diel periodicity in order to maximize growth in stratified environments (Eppley et al. 1968, Heaney \& Eppley 1981, Cullen 1985, Kamykowski \& McCollum 1986). Given the swimming speed of $M$. rubrum, it is however conceivable that migrations need not be performed with diel periodicity, and observed changes in distribution may represent the 'dynamic summation' of a population in which cells migrate according to the need for balancing individual requirements for carbon and nitrogen. With such a high photosynthetic efficiency (e.g. Smith \& Barber 1979, Platt et al. 1980, Stoecker et al. 1991) cells would theoretically need to spend only about $1.3 \mathrm{~h}$ each day above the $I_{\mathrm{k}}$ depth in order to satisfy diel respiratory demands (assuming $R=0.7 \%$ cell $\mathrm{C} \mathrm{h}^{-1}$ and $P_{\max }=12.5 \%$ cell $\mathrm{C} \mathrm{h}^{-1}$ as discussed earlier). This, of course, ignores the costs of locomotion itself which are unknown but potentially significant (Crawford 1992b). Cells maintained in darkness for several days show reduction in chlorophyll content and chloroplast number (Lindholm 1985, Crawford pers. obs.), whereas cells sampled from these deep maxima, at almost zero irradiance, are rich in chlorophyll and appear to photosynthesize normally (Lindholm \& Mörk 1990). This suggests that individuals visit the surface at fairly regular intervals.

This study does not clearly illuminate the principal factor regulating vertical distribution and migration, but it is likely that a combination of factors are invoived, and, indeed, a number of potential factors were unavoidably omitted. For example, the potential role of predators either directly through feeding or indirectly through provocation of avoidance reactions (e.g. see Jonsson \& Tiselius 1990) was not evaluated. Similarly, the role of excretion or upward diffusion of reduced forms of nitrogen was not considered. However, the necessities of sampling design imposed by the peculiarities of Mesodinium rubrum itself (as discussed earlier) dictated that consideration of all possible factors was not feasible. Moreover, artefactual changes in ver- tical distribution cannot be ruled out because migration potential was a constant logistical complication hampering temporal and spatial sampling design. Improved future understanding of the migration of this species will only be realized with a much more dynamic approach to sampling in order to minimize the possibility that migration might be quicker than data collection.

This study does however present convincing new evidence that essentially discounts either positive or negative reactions to irradiance as a simple factor driving diel migrations. Earlier studies which suggested phototaxis as a major factor driving migrations (e.g. Bary \& Stuckey 1953, Smith \& Barber 1979) have been much cited, although these were in fact based upon tew data in the original publicdions. Mesodinium rubrum does respond to light (e.g. Lindholm 1981), and it is likely that phototaxis is involved under certain circumstances, but probably mediated by additional tactors. It seems that these factors do not drive simple bulk reactions since the population clearly does not respond in a uniform manner (Figs. $2 \& 3$; see also Lindholm \& Mörk 1990).

The major population maximum usually coincided with the thermocline, approximately marked by the 5 and $10^{\circ} \mathrm{C}$ isotherms (Figs. 1-4). There is little evidence that distribution of Mesodinium rubrum is directly limited by temperature (e.g. see Lindholm \& Mörk 1990), but with little density gradient afforded by only a slight halocline, temperature was probably the main influence on the stability of the water column. Crawford \& Purdie (1992) presented evidence from a dynamic estuary that $M$. rubrum avoided near-surface turbulence and aggregated in relatively stable zones. Further evidence is emerging of the potential role of water column stability in development (Crawford et al. 1997) and dynamics (Cloern et al. 1994) of red tides caused by this species. It is possible that a proportion of the population of $M$. rubrum aggregated in the thermocline as the zone of greatest stability in Inre Verkviken, however, this cannot be confirmed as measurements of dynamic stability of the water column were not taken and indeed are not routine measurements in biological studies (e.g. see Crawford \& Purdie 1992). Inre Verkviken was rhosen as a relatively stable environment, but avoidance of wind-induced near-surface turbulence might explain, to some extent, the varying degrees of surface avoidance observed. It has been observed that surface accumulations of $M$. rubrum are more prevalent on calm days than windy ones (Lindholm 1981), but surface accumulations are also common in autumn, even with a very weak thermocline. Clearly the issue of the role of water column stability requires further clarification and dynamic stability should become a routine measurement. 
Despite the choice of Inre Verkviken as a site with minimal advective influences (see 'Introduction'), changes in total integrated populations were observed to occur during individual sequences of profiles. However, it is unclear whether these changes represent real changes due to the influence of advection, cell division and grazing, or whether they represent artefactual variation due to the aggregation of this species. The degree to which sampling interval coincides with population maxima, together with the magnitude of maxima, will determine how well the real integrated population is estimated. The error associated with estimates of total integrated population is impossible to determine as this would require a stable population of known abundance.

Highest accumulations of Mesodinium rubrum in Inre Verkviken have occurred in autumn (Lindholm 1981, Lindholm \& Mörk 1990) and seem to be associated with events which increase nutrient concentration close to the surface; for example winds, erosion of the thermocline or rainfall. This poses the question what limits $M$. rubrum here in summer? The absence of red water when irradiance and nutrients are vertically separated but 'within reach' (in less than 1 h) suggests that there could indeed be a significant metabolic cost involved in exploitation of the water column (see Crawford 1992b). However, caution in the interpretation of 'red water' is required; the working definition of visible red water for $M$. rubrum is often given as abundances of over 200 cells $\mathrm{ml}^{-1}$ (McAlice 1968), with abundances typically of around 1000 to 2000 cells $\mathrm{ml}^{-1}$ in dense red water (Crawford et al. 1997). Abundances in Inre Verkviken reached 200 cells $\mathrm{ml}^{-1}$ on one occasion (Fig. 3), but were more typically of the order 10 to 100 cells $\mathrm{ml}^{-1}$ as a mean abundance through the water column (Figs. 1-3); at least an order of magnitude lower than in dense red water. However, if all cells had concentrated near the surface, the abundances observed in Inre Verkviken could have been categorized as red water. A more workable definition of red water in terms of integrated water column abundance (cells $\mathrm{m}^{-2}$ water surface) could be more useful; for example red tides in the Southampton Water estuary (UK) are characterized by integrated abundance of $M$. rubrum of the order of $1000 \times 10^{6}$ to $2000 \times 10^{6}$ cells m ${ }^{-2}$ (Crawford et al. 1997). Placed in this context, the abundances in Inre Verkviken (Figs. 1-3) were relatively stable over the study period, of the order $550 \times 10^{6}$ to $900 \times$ $10^{6} \mathrm{~m}^{-2}$ and in fact only a factor of 2 lower than dense red water values. Whilst it is not suggested that red water is always formed just by simple accumulation of cells, it is clear that in summer and autumn in Inre Verkviken, factors promoting development of 'visible red water' could have more to do with factors regulating vertical distribution than previously anticipated.
Acknowledgements. This research was funded by the Royal Society 'John Murray Travelling Fellowship in Limnology and Oceanography' to D.W.C. We thank Maud Karlsson for assistance with field sampling and analysis of samples. Prof. Michael Sleigh, Dr Duncan Purdie, Dr lvan Heaney, Dr John Dolan and 3 anonymous referees made constructive comments on earlier versions of the manuscript.

\section{LITERATURE CITED}

Bary BM. Stuckey RG (1953) An occurrence in Wellington Harbour of Cyclotrichium meunieri Powers, a ciliate causing red water, with some additions to its morphology. Trans R Soc NZ 78:86-92

Cloern JE, Cole BE, Hager SW (1994) Notes on a Mesodinium rubrum red tide in San Francisco Bay (California, USA). J Plankton Res 16:1269-1276

Crawford DW (1989) Mesodinium rubrum: the phytoplankter that wasn't. Mar Ecol Prog Ser 58:161-174

Crawtord DW (1992a) The physiological ecology of the redwater ciliate Mesodinium rubrum. PhD thesis, University of Southampton

Crawford DW (1992b) Metabolic costs of motility in planktonic protists: theoretical considerations on size scaling and swimming speed. Microb Ecol 24:1-10

Crawford DW (1993) Some observations on morphological variation in the red-water ciliate Mesodinium rubrum. $J$ Mar Biol Ass UK 73:975-978

Crawford DW, Purdie DA 11992) Evidence for avoidance of flushing from an estuary by a planktonic, phototrophic ciliate. Mar Ecol Prog Ser 79:259-265

Crawford DW, Purdie DA, Lockwood APM, Weissman P (1997) Recurrent red-tides in the Southampton Water estuary caused by the phototrophic ciliate Mesodinium rubrum. Estuar Coast Shelf Sci (in press)

Cullen JJ (1985) Diel vertical migration by dinoflagellates: roles of carbohydrate metabolism and behavioural flexibility. In: Rankin MA (ed) Migration: mechanisms and adaptive significance. Contr Mar Sci 27 (suppl):135-152

Dale T (1987) Diel vertical distribution of planktonic ciliates in Lindåspollene, western Norway. Mar Microb Food Webs 2:15-28

Eppley RW, Holm-Hansen O, Strickland JDH (1968) Some observations on the vertical migration of dinoflagellates. J Phycol 4:333-340

Grasshoff K (ed) (1976) Methods of seawater analysis. Verlag Chemie, Weinheim

Heaney SI, Eppley RW (1981) Light, temperature and nitrogen as interacting factors affecting diel vertical migration of dinoflagellates in culture. J Plankton Res 3:331-345

Jonsson PR, Tiselius P (1990) Feeding behaviour, prey detection and capture efficiency of the copepod Acartia tonsa feeding on planktonic ciliates. Mar Ecol Prog Ser 60: $35-44$

Kamykowski D, McCollum SA (1986) The temperature acclimated swimming speed of selected marine dinoflagellates. J Plankton Res 8:275-287

Krainer KH, Foissner W (1990) Revision of the genus Askenasia Blochmann, 1895, with proposal of two new species, and description of Rhabdoaskenasia minima n. g., n. sp. (Ciliophora, Cyclotrichida). J Protozool 37:414-427

Lindholm T (1981) On the ecology of Mesodinium rubrum (Lohmann) (Ciliata) in a stagnant brackish basin on Aland, SW Finland. Kieler Meeresforsch, Sonderh 5:117-123

Lindholm T (1985) Mesodinium rubrum - a unique photosynthetic ciliate. Adv Aquat Microbiol 3:1-48 
Lindholm $T$ (1992) Ecological role of depth maxima of phytoplankton. Arch Hydrobiol Beih Ergeb Limnol 35 $33-45$

Lindholm T (1996) Periodic anoxia in an emerging coastline lake basin in SW Finland. Hydrobiologia 325:223-230

Lindholm T, Mörk AC (1990) Depth maxima of Mesodinium rubrum (Lohmann) Hamburger \& Buddenbrock - examples from a stratified Baltic Sea inlet. Sarsia 75:53-64

McAlice BJ (1968) An occurrence of ciliate red-water in the Gulf of Maine. J Fish Res Bd Can 25:1749-1751

Owen RW, Gianesella-Galvāo SF, Kutner MBB (1992) Discrete, subsurface layers of the autotrophic ciliate Mesodinium rubrum off Brazil. J Plankton Res 14:97-105

Parsons TR, Maita Y, Lalli CM (1984) A manual of chemical and biological methods for seawater analysis. Pergamon Press, Oxford

Passow U (1991) Vertical migration of Gonyaulax catenata and Mesodinium rubrum. Mar Biol 110:455-463

Plati $T$, Galiegos CL, Harrison WG (1980) Photoinhibition of photosynthesis in natural assemblages of marine phytoplankton. J Mar Res 38:687-701

Smith WO, Barber RT (1979) A carbon budget for the auto-

Responsible Subject Editor: John Dolan, Villefranche-surMer, France trophic ciliate Mesodinium rubrum. J Phycol 15:27-33

Sorokin YuI, Kogelschatz J (1979) Analysis of heterotrophic microplankton in an upwelling area. Hydrobiologia 66: 195-208

Soulsby PG, Mollowney M, Marsh G, Lowthion D (1984) The role of phytoplankton in the dissolved oxygen budget of a stratified estuary. Water Sci Technol 17:745-756

Small EB, Lynn DH (1985) Phylum Ciliophora. In: Lee JJ, Hutner SH, Bovee EC (eds) An illustrated guide to the Protozoa. Society of Protozoologists, Lawrence, KS, p $393-440$

Stoecker DK, Putt M, Davis LH, Michaels AE (1991) Photosynthesis in Mesodinium rubrum: species-specific measurements and comparison to community rates. Mar Ecol Prog Ser 73:245-252

Taylor FJR, Blackbourn DJ, Blackbourn J (1971) The redwater ciliate Mesodinium rubrum and its 'incomplete symbionts': a review including new ultrastructural observations. I Fish Res Bd C.an 28:391-407

Throndsen J (1978) Preservation and storage. In: Sournia A (ed) Phytoplankton manual. Monographs on oceanographic methodology 6. UNESCO Press, Paris, p 69-74

Manuscript received: April 12, 1996

Revised version accepted: July 3, 1997 